\title{
Historical-Cultural Neuropsychology: a systemic and integral approach of psychological functions and their cerebral bases.
}

Yulia Solovieva. Benemérita Universidad Autónoma De Puebla (BUAP)

Luis Quintanar Rojas. Benemérita Universidad Autónoma De Puebla (BUAP)

Tatiana Akhutina. Moscow State University

Izabel Hazin. Universidade Federal do Rio Grande do Norte

\begin{abstract}
This article analyzes the theoretical foundations of neuropsychology based on the ideas of L.S. Vygotsky and A. R. Luria, with an emphasis on the principle of systemic organization of psychological processes, their ontogenetic development and systemic representation in the central nervous system. The article describes the need for a comprehensive study of neuropsychology, considering its relationship with more global psychological concepts developed by representatives of the historical-cultural concept of mental functions and the theory of activity. This paper considers the need to include neuropsychology in the context of historical-cultural studies and the theory of activity. Finally, it is argued that one of the essential features of historical-cultural neuropsychology is the concept of systemic, dynamic and hierarchical representation of cultural psychological processes.
\end{abstract}

Keywords: neuropsychology; Vygotsky; Luria; Historical-Cultural.

\section{Resumo}

Neuropsicologia Histórico-Cultural: uma concepção sistémica e integral acerca dos fenômenos psicológicos e suas bases cerebrais. O presente artigo dedica-se à análise dos fundamentos teóricos da neuropsicologia a partir das ideias de L.S. Vygotsky e A. R. Luria. Enfatiza-se o principio da organização sistêmica dos processos psicológicos, seu desenvolvimento ontogenético e sua representação sistêmica no sistema nervoso central. $O$ artigo descreve a necessidade de um estudo integral da neuropsicologia, considerando sua relação com as concepções psicológicas mais globais, desenvolvidas pelos representantes da concepção histórico-cultural e da teoría da atividade. Propõe-se a consideração da necessidade de inclusão da neuropsicologia no contexto dos estudos histórico-culturais e da teoría da atividade. Por fim, argumentam e problematizam acerca de um dos aspectos essenciais da neuropsicologia histórico-cultural, a saber, a concepção da representação sistêmica, dinâmica e hierárquica dos processos psicológicos culturais.

Palavras-chave: neuropsicologia; Vygotsky; Luria; histórico-cultural.

\section{Resumen}

Neuropsicología Histórico-Cultural: una concepción sistémica e integral acerca de fenómenos psicológicos y sus bases cerebrales. El artículo se dedica al análisis de los fundamentos teóricos de la neuropsicología desde las ideas de L.S. Vygotsky y A.R. Luria. Se realiza énfasis en el principio de organización sistémica de los procesos psicológicos, su desarrollo ontogenético y su representación sistémica en el sistema nervioso central. $O$ artículo describe la necesidad de un estudio integral de la neuropsicología, considerando su relación con las concepciones psicológicas más globales, desarrolladas por los representantes de la concepción histórico-cultural y la teoría de la actividad. Propone considerar la necesidad de inclusión de la neuropsicología en el contexto de los estudios históricoculturales y la teoría de la actividad. Uno de los rasgos esenciales de la neuropsicología histórico-cultural es la concepción de la representación cerebral sistémica, dinámica y jerárquica de los procesos psicológicos culturales.

Palabras clave: neuropsicología; Vygotsky; Luria; histórico-cultural. 
The intention of this article is to share the fundamental theoretical principles of the neuropsychological approach based on the historical-cultural concept. The approach was initially proposed by L.S. Vygotsky and continued by A.R. Luria, both of whom use some key or essential aspects without covering the entire conceptual theoretical apparatus, methodology and application of neuropsychology from the approach. They argue that the term itself ("historical-cultural neuropsychology") should be considered valid within the theoretical-methodological concepts of contemporary neuropsychology.

One of the key aspects to revisit is the idea of a systemic, integral and dialectical approach to the relationship between psychological processes and the basic material substrate, understood here as the central nervous system (CNS). It is argued that, unlike psychology, for neuropsychology it is particularly relevant to specify and study the relationship between psychological processes and the CNS, that is, between the mind (psychological processes) and the brain (material substrate of these processes). The philosophical dilemma between the ideal and the material and the psychophysiological dilemma about the possible relationship between the physiological and psychological level of cognitive and affective processes are well known.

It is important to underscore that this is a relevant and central problem in historical-cultural psychology. In his writings and transcribed oral presentations, L.S. Vygotsky has never refused to consider this problem, but rather expressed ideas and points of view that are still valid and debatable for the current development of the neurosciences and neuropsychology.

The close relationship between psychological processes and their cerebral bases is sometimes disregarded by representatives of the historical-cultural approach in psychology who attempt to reduce historical-cultural studies to sociological, anthropological or intersubjective aspects, as if neuropsychology and historical-cultural concepts were detached and separated from the discourse of the historical-cultural psychologist, as if historical-cultural psychologists were never neuropsychologists and neuropsychologists not representatives of the historical-cultural concept (Mahn, 2010; Toomela, 2014; Veresov, 2010).

In addition, it is precisely neuropsychology, created and disseminated by Luria and his followers, that provides a systemic and integral perspective of the relationship between psychological processes and their cerebral bases. The intention is to solve the dilemma of the relationships that exist between the mind and the brain, which is not clearly explained in neuropsychology or cognitive neurosciences that postulate a static and unilateral relationship between psychological processes and brain structures or, at least, does not exhibit a clear expression of this relationship's dependence on the effects of cultural development.

Human cultural development, which is subject to constant historical and social transformations, is by definition a dynamic and flexible process that depends on constant changes at all levels of organization in society, such as linguistic, educational, communicative, technological and object phenomena. This topic is relevant for a child's psychological development, because children move from one type of interaction with society to another, whereby the type of interaction determines the dynamic and qualitative changes in their activity and personality (Vygotsky, 1982).

Given this position, it is impossible to disregard the importance of dynamic and qualitative changes in children's' lives in terms of establishing the changes that arise in the representation of psychological processes in the CNS. However, this seems to go unnoticed by the representatives of the cognitive sciences, who continue to cite fixed "centers" and "locations" in the CNS. References to "language centers", "face perception centers", and "verb centers" can be found in a number of studies.

How can one refer to centers (bases) of language, when newborn babies cannot speak? These bases are formed according to their cultural acquisition of language, provided they interact with adults, with the emergence of dynamic and flexible functional systems in order to understand and produce oral and written language.

These "bases" can only be consolidated as a cultural probability in accordance with the child's own cultural activity, emerging based on the participating levels and connections of the CNS. Thus, human beings are not only subjects of their own activity, following the expressions of Leontiev (1975), but also, indirectly, involuntary participant-shapers of the cerebral bases of all these activities.

\section{The systemic position about the relationship between psychological processes and their cerebral bases}

The important historical moment and text that justify our position date from October 9, 1930, when L.S. Vygotsky gave the lecture "About psychological

Estudos de Psicologia, 24(1), janeiro a março de 2019 , 65-75 
systems" (Vygotsky, 1982), which contains some of the fundamental ideas that prompted the subsequent development of the version of neuropsychology of A.R. Luria, his close collaborator, friend and follower. Both authors return to a systemic and integral vision of psychological phenomena and their representation in the material substrate of the CNS: the human brain. This vision is contrasted by another position that can be found in psychology and neuropsychology, namely the atomistic and insulating version that aims to study psychological phenomena as individual and unique entities, each with its own definitive relationship with certain material structures in the brain.

Undoubtedly, every researcher or professor has a certain vision or position about the phenomena and objects they study. A philosophical and methodological analysis makes it possible to identify and discriminate these positions.

According to Russian philosopher Stiopin, the non-traditional systemic view in science, often called non-classical science, can be related to three criteria. The first involves identifying the particularities of the systemic organization of the objects of study and the images of the world that conform to the thinking subject.

The second criterion is determining the particularities of the means and operations of research activities, and the third the particular orientations of the objectives and values of the subject of the research activity together with a reflection on them. The latter forms the basis of the philosophical view of science that the researcher follows or accepts (Kiyaschenko \& Stiopin, 2009).

The positions expressed by Vygotsky in the text "About psychological systems" and the subsequent works of A. R. Luria correspond to this systemic, integral and dialectical vision of the relationship between the psychic and the cerebral. What supports this viewpoint?

As an example, we can cite Vygotsky's words regarding the idea of representation of psychological processes in the brain. Surprisingly, he writes that none of the functions are ever related to the work of a single center, but are the product of integral activation of the strictly differentiated and hierarchically related centers (Vygotsky, 1982). This demonstrates Vygotsky's systemic idea that brain participation is the material basis of psychological processes, that is, a psychological process should always be considered a dynamic and complex system of material brain participations.

Later, Vygotsky writes that the idea of a chronogenous location means that a complex function is understood as a set of operations performed by a series of brain devices and sectors in a specific sequence to form a melody with its own configuration, structure and regularities (Vygotsky, 1982). He also refers to the complex concept of the functional system that emerges later in physiology and neuropsychology (Anokhin, 1987; Luria, 2003). Vygotsky anticipates this concept and refers to dynamic constellations that are shaped and changed throughout the ontogeny, whose content can be analyzed in terms of its structure and regularities.

Views on the relationship between psychological processes and the brain have a long history. As such, it is important to emphasize that the ideas expressed by Vygotsky in the aforementioned text and reiterated by Luria in his research do not appear in a vacuum, but are based on the previous or contemporary philosophical ideas of the authors. Likewise, just as in philosophy there is no consensus or a single philosophical theory, in psychology, a science that can be considered one of the daughters of philosophy, there is no single viewpoint regarding the origin and functioning of psychological processes.

The concept of philosophical science as a study of human consciousness emerged in the seventeenth century, with this same object of study adopted in the psychology of the nineteenth century (Zhdan, 2004). Data generalization was the main method used to construct a theory and is obtained through experience. It was initially an introspective, subjective experience of the study participant, who was also a researcher and subject of study. Thus, while natural sciences deal with the world of objects, psychology is the world of consciousness of each subject.

Under this meaning, subjects are both researchers and the objects of their experiment, applying the "introspection" method by feeling, experiencing and recording their own awareness. Thus, as a method in any natural or psychological science, it is the inductive experimental method that records and generalizes experiences (Kiyaschenko \& Stiopin, 2009). In this same stage of shaping sciences, an attempt is made to locate or represent the psyche as consciousness in some material sectors (Luria, 1969).

In the $18^{\text {th }}$ and $19^{\text {th }}$ centuries, the locationists tried to find brain zones for different abilities and elements of psychic life. Hall's phrenology was replaced by Broca's attempt to locate the motor word centers and Wernick's to find sensory word centers (Xomskaya, 2005). A different concept was expressed by representatives of the opposite point of view, who considered 
the brain an indivisible unit that participated in the behavioral processes. We want to point out that each of these positions contained its share of true rationality. Localizationism claimed that there are specialized sectors in brain functioning, while antilocalizationism stated that the brain works as a whole. However, a dialectical concept was needed to unify both points of view without contradictions.

To that end, a non-classical or dialectical outlook was needed to understand the functioning of complex systems that cannot be limited to the analysis of their components or the contrary consideration of an indivisible unit. Complex systems consist of elements, but not limited to them. The operation of a system cannot be explained as the sum of the elements, but rather as an integral product of each element's contribution.

The semiologist Lotman proposed that human culture can be understood as a complex system of constant self-regulation and self-renewal. These systems underlie the course of life in human society that cannot be understood without its cultural mechanisms. Cultural exchange is one of these mechanisms (Lotman, 2001). Complex functional systems in physiology were proposed by Bernstein (2003) and Anokhin (1987). These systems underlie the life of each organism at various levels of biological evolution. Biological necessity as an objective of future action is one of the mechanisms that shapes functional systems (Bernstein, 2003).

All complex autoregulation systems guarantee their operation through information and direction processing with the help of direct and indirect return afferents. Since mechanistic determinism is insufficient to explain the dynamic changes in these systems, there is a need for relative or probabilistic determinism (Kiyaschenko \& Stiopin, 2009). Thus, we can assume that the relationship between psychological processes and their cerebral bases should be considered a probability and not a postulate.

One of the examples of a non-classical point of view was the cerebral representation of psychological processes and their location, as put forth in the theory of English neurologist $\mathrm{H}$. Jackson. In the 1860 s, this author expressed ideas contrary to those of Broca and Wernicke (Luria, 1969). He was against attempts to locate human abilities in specific centers, considering them complex functions and expressing their dependence on work at various levels of the CNS (Bernstein, 2003).

According to Jackson, each function was represented at lower and higher levels of the brain. The lower level consisted of the spinal cord and the brainstem, the intermediate level, the primary motor and sensory sectors, and the upper level, the frontal lobes (Luria, 1969). The higher levels involve a greater degree of voluntary functions, while the lower levels a lower degree, that is, exhibited more spontaneous manifestations (York \& Steinberg, 2006). The levels of organization of the functions are in a particular hierarchy, with each ensuing level, being more evolutionarily advanced, built on a lower level.

In the face of a pathological process, the first to suffer are evolutionarily superior formations, leaving the oldest formations without "voluntary control". Pathological processes can lead to negative symptoms in the absence of voluntary control, as well as positive symptoms such as the release of this control (York \& Steinberg, 2006). The author underscores the possibility of self-regulation of these systems with the intervention of lower levels in cases of pathology.

Vygotsky (2016) expresses the three laws of emancipation of nerve centers. The first of these laws is called "the function stage". "This means that functions that were initially performed with the lower centers of the brain during development begin to be performed with the higher centers" (Vygotsky, 2016). This phenomenon is true for both phylogenesis and ontogenesis. For example, the direction of movement in birds is controlled by the cerebellum, which is dependent on the cerebral cortex in mammals.

The second law refers to the fact that during the development and movement of functions upwards, the lower centers are not totally separated from that function, but "participate in it as a substance subordinated to the higher centers" (Vygotsky, 2016). This position presumes that in the same function different levels of brain organization participate in different ontogenetic moments.

The third law establishes different effects for injuries or decompensations that can occur in the brain of adults or children. In the case of weakening of an adult's upper center, the function immediately passes to the respective center below the injury. This lower center resumes its independent performance from the previous stages of development. On the other hand, injury to a child's lower center affects all the upper centers that should take part in this function. If the brain center of an adult is affected, the center below it suffers, whereas an affected center in childhood

Estudos de Psicologia, 24(1), janeiro a março de 2019 , 65-75 
means the center above it that participates in the same function will also suffer (Vygotsky, 2016).

This allows us to understand that the consequences of brain injuries and immaturity differ in children and adults. Bernstein writes that "a chronogenous location", that is, different correlations in the locations of the same function in different periods of its development, are clearly illustrated in Vygotsky's observations and in the laws he established regarding the development and disintegration of functions. Bernstein agrees with Vygotsky's laws and that the correlations between various brain sectors change during development. We can assume that psychological actions involve mechanisms participating at different subcortical and cortical levels and that, the smaller the child, the greater the participation of subcortical levels in their functional systems.

In relation to levels of organization, Bernstein developed the systemic concept about the levels of psychophysiological organization of complex human movements, underscoring that each movement is carried out at different levels simultaneously, with each level participating according to the conditions and objective of each movement. From the concept described, the psychophysiological bases of movements can be considered from their hierarchical, dynamic and systemic organization, which can never be reduced to the same type or level of organization in the CNS. The organization level of the sphere of movements depends on the objective of the action, voluntary or involuntary aspect, the degree of automation and the real conditions of the given situation that led to the movement (Luria, 2003).

It is important to underscore the fact that in his book Bernstein (2003) quotes both Vygotsky and Jackson, demonstrating the necessary representation of a complex function, such as a motor act or human movement directed at various levels of the peripheral and central nervous system.

This is extremely important in understanding the roots of the complex functional system in non-classical physiology. Given this position, it is not surprising that the peripheral nervous system (or subcortical levels) can perform complex functions (motor reactions) due to the disconnected participation of the upper brain centers or to the pathological or artificial separation of the cerebral hemisphere, since this is observed in the "divided brain" experiments.

This eliminates the need to look for a "homunculus" located in the prefrontal areas and "regret their absence", because other levels of the nervous system are responsible for performing tasks of movement recognition and execution when the upper levels are excluded or disorganized (Gazzaniga, 2012).

As previously indicated, on October 9, 1930, L.S. Vygotsky introduced his paper "About psychological systems" at the Clinic of Nervous Diseases of Moscow State University. Why is this paper considered so important?

Causality changes in post-classical science; complex systems are characterized as very different open systems, with the capacity for self-reorganization and exchange with external effects. In addition, the emergence of more complex levels due to previous causes affects return afferentation, whereby the consequence functions as the cause of future changes. In other words, cause-effect relationships are constantly changing. A historical, dialectical and flexible vision of a process and consideration of its constant changes and modifications is proposed (Kiyaschenko \& Stiopin, 2009).

A useful example for neuropsychology may be that, with the child's acquisition of reading and writing, its level of oral language expression changes, which can lead to effective communication or acquisition of intellectual abilities, including enhanced reading and writing. This does not rule out the claim that the possibilities of acquiring literacy in a child are based on the previous level of their oral language development. On the other hand, in some clinical cases of adult patients with brain damage, absolutely disintegrated oral language must necessarily be based on prior rehabilitation of the reading and writer process, which can lead to gradual progress in their oral language.

These changes are observed in adult patients with dynamic aphasia (Akhutina, 2002). We consider that the examples presented of a "non-classical" position are opposed to a linear viewpoint, which suggests total separation and independence of oral language and literacy, or forced rehabilitation of oral language before reading and writing.

The title of Vygotsky's presentation demonstrates the importance of the systemic nature of psychological processes: psychological systems. Vygotsky states that "in the development process, and historical development in particular, it is not so much the functions that change, as we have studied before (and this was our mistake), or their structure, but rather that new groupings arise in the relationships between the functions, which were not known in the previous steps" (Vygotsky, 1982). The most important part of the paper, according to Vygotsky, is the 
relationship between new systems and their substrate, that is, the brain (Vygotsky, 1982).

What does Vygotsky mean? What was this error?

A process of internalization of habits or means arises, whereby the child perceives an object and compares it with another, etc. These studies have led us to a dead end, while others have clearly shown that the development of perception is modified because it is included in a complex synthesis with other functions, for example, language" (Vygotsky, 1982).

Vygotsky states that as a consequence of the systemic principle that "the upper and lower functions are not built on two floors", he rejects the previous ideas expressed in his earlier texts about a division between natural and cultural functions. In 1932, Vygotsky wrote that "voluntary attention is a domain of involuntary attention, which can mean these two floors" (Zavershneva, 2008). The new functional systems work according to the new regularities (Vygotsky, 1982; 1984). These viewpoints are similar to those of the Russian physiologists N. Bernstein and P. Anokhin, who developed their own concepts of systems with complex functions and the different levels that they encompass.

Starting with the location of new systems in the brain, Vygotsky begins to discuss this issue in the context of the social genesis of higher psychological functions, in which internalization is related to the formation of interfunctional relationships. This will be discussed in detail. With respect to voluntary action, Vygotsky identifies three stages of internalization.

First, there is the interpsychological stage: I order, you execute; then we move to the extrapsychological stage: I start talking to myself; followed by the intrapsychological stage: two points in the brain, which are externally activated, begin to act in a single system and become an intracortical point (Vygotsky, 1982, p. 130).

As a response to external behavior, a functional system emerges that includes various components. An external grouping or mediatization, such as the use of external media, produces the need to form internal relationships, in other words, a functional system. Vygotsky calls this internalization "extra cerebral organization" within the functional system or as a structural and functional unit (Vygotsky, 1982).

In relation to the location of higher psychological functions, Vygotsky states that "the cerebral substrate of psychological processes must be understood not as isolated sectors, but as the complex systems of the entire cerebral apparatus," in which "a number of different sectors collaborate" (Vygotsky, 1982).

Thus, in the 1930 conference, Vygotsky tried to formulate the principle of the systemic organization of higher psychological functions, relating it to the social genesis principle of these same functions. In the studies of other authors who defended this principle, there was no relationship between systemic organization and genesis.

In the concept of functional systems formulated by Anokhin (1987), the importance of the unit of analysis of systems for physiology in general is considered, without differentiating between studies with animals and humans. Even physiology may exhibit a systemic posture that analyzes various levels of the central and peripheral nervous system during the performance of tasks in animals. On the other hand, the non-systemic position is limited in its description of the participation of structures on a same level; for example, cortical structures (Machinskaya, 2012).

Bernstein (2003) places special emphasis on the importance of considering systemic physiological and psychophysiological studies, including the very strong position of the social and cultural genesis of these processes. In 1975, Luria wrote that systemic psychophysiology has yet to develop as a science. Leontiev (1975) has always stressed the need to include the systemic nature of human activity in experiments and the possibilities of its formation from the external to the internal level.

We can see that contemporary and post-Vygotsky authors have reiterated his ideas about the principles of social genesis and systemic organization. With regard to Luria and Leontiev, we can assume that they developed these ideas from coexisting and collaborating with Vygotsky, while Bernstein and Anokhin reached a similar conclusion from the data of physiological studies. Both paths suggest the usefulness of these principles for neuropsychology and experimental neurophysiology (Machinskaya, 2012).

In addition, in the text cited above, Vygotsky also introduced a very important third principle for neuropsychology: the dynamic organization of higher psychological functions. Vygotsky's conference concludes with the words: "It seems to me that the systems and their destiny are the alpha and omega for us and our future work" (Vygotsky, 1984).

Another significant contribution by Vygotsky was the paper entitled "Diagnosis of the development and pediatric clinic of a difficult childhood", written in 1931 
(Vygotsky, 1983), which contains recommendations for the psychological evaluation of children. Its objective is a positive characteristic of children and identification of their weaknesses. The positive characteristics should help determine useful recommendations for proper parenting and whether this is appropriate or not for the common public school.

In his 1932 lecture at the Psychoneurological Academy of Ukraine, "About the work plan for genetic and clinical psychology", based on the systemic principle, Vygotsky reaches an important conclusion about the need for "psychological qualification of symptoms", that is, dividing them into the primary and secondary.

The primary symptoms represent the product of altered peripheral or central brain structures, while the secondary symptoms arise as a result of the inappropriate social situation for the child's development. This idea reflects the systemic principle that Vygotsky proposed to diagnose childhood problems, insists on qualitative analysis of the difficulties that arise.

This approach became the fundamental feature for the entire theory of neuropsychological diagnosis, later developed by Luria (2003). The same approach is currently applied by his followers (Akhutina \& Pilayeva, 2008; Solovieva \& Quintanar, 2017a, 2017b).

Finally, on April 28, 1934, in his last presentation, Vygotsky discovers the principle of dynamic and systemic organization and the location of higher psychological functions. The consequence of this principle is that, according to Vygotsky, a same injury leads to absolutely different consequences due to its location in adults and children. In the case of the child, it is largely the upper levels that suffer, whose incomplete development requires the participation of the lower levels in accordance with the principle of systemic organization. In adults, the lower levels suffer and the defect is compensated for by the upper level, which have fully developed (Vygotsky, 1982).However, it is important to underscore that this relative regularity depends not only on the type and degree of the injury, but also on the type of cultural interactions the child is exposed to.

Thus, a partial deficit in the child, such as weak visual perception, may hamper the development of most other functions, for example, poor vocabulary, and changes in language and logical-verbal thinking (Vygotsky, 1995), a situation later called "cascading developmental effect" (Karmiloff-Smith, 2002).

However, in addition to exhibiting a negative meaning as complementary complications, secondary formations, may also have a compensatory aspect, reflecting the high plasticity of a child's brain. That is precisely why secondary symptoms can be better solved "from pedagogical interaction" (Vygotsky, 1983).

In addition to discussing development in the context of various contrary trends, Vygotsky promotes development as a probabilistic, continuous process, subject to complex self-organization, that is, a process, in which all stages unfold "as if acting in a drama" (Vygotsky, 1983). According to Vygotsky, the main objective of a pedagogical study is "to discover the internal logic of the drama of child development" (Vygotsky, 1983).

Thus, Vygotsky's dynamic and causal approach was aimed at identifying the internal regularities of development, discovering the primary mechanisms of change and separating them from secondary and tertiary formations, instead of finding symptoms and difficulties, as is customary until now in the clinic of difficulties in development and school learning.

\section{Neuropsychological theory as a systemic theory}

Vygotsky's position in these texts and presentations, made late in life, were reiterated and developed in neuropsychology, first by Luria, with regard to neuropsychology, but it is also important to underscore that all the authors mentioned here were assisted by groups of collaborators and students. In addition, it should be noted that other authors have used the same approach, not necessarily in neuropsychology, but in areas of developmental (Elkonin, Bozhovich, Zaporozhech) educational, pedagogical (Galperin, Talizina, Leontiev), and general psychology (Rubinsten, Leontiev, Smirnov), although it would not be feasible to mention all of them here.

Luria began his work as a medical doctor at the Institute of Neurosurgery of N. N. Burdenko in Moscow in 1937 . He created a system of neuropsychological diagnosis methods related to changes in higher psychological functions caused by local brain lesions. While developing these methods, he relied on the systemic structure of the higher psychological functions proposed by Vygotsky, and considered them to be functional systems that include a multitude of elements.

There is no doubt that Luria also relied on the work of physiologists who proposed a systemic concept corresponding to the vital needs of the organism in animals and humans. Functional systems always conform 
depending on the objective and anticipated result that must be achieved under the given conditions. This notion is similar to the concept of Leontiev's activity theory (1983), underscoring that human goals and means are always products of human culture. Functional systems also vary with the objectives and means. This refers to the potential high plasticity and flexibility of various CNS levels of the functional systems (Luria, 2003).

According to Luria, each link in the functional system is related to a specific aspect of psychological function and is guaranteed by various levels of brain activity. Psychological functions are based on "complex systems, each making its own contribution to the complex psychological processes that may be located far from the brain" (Luria, 2003, p. 77). When the work of one of the links is altered, so is that of the entire system. "This change also depends on the specialization of each of the elements of the functional system" (Luria, 2003, p. 77).

The diagnosis system proposed by Luria made it possible to assess all the links of various functional systems under the new logic of its "similarity to the syndrome". He suggested that syndromic analysis involves a detailed qualification of symptoms. In other words, it was a correlation of some symptoms and their main related factors with other symptoms that appeared according to the laws of the systemic organization of higher psychological functions. At the same time, the conserved aspects of each patient should be determined (Xomskaya, 2005).

It is important to underscore that this qualitative proposal in the neuropsychological clinic is not limited to an empirical description of phenomena and difficulties, as is often the case. The current dichotomy that exists in the neuropsychological analysis of cases refers on one hand to an alternative analysis based on numerical data obtained in psychometric procedures and, on the other, a description of the difficulties, based on observation and identification of the parameters of psychological functions such as language, attention, memory, some personality data and / or the social environment of the child's life.

None of these alternatives is related, as such, to the idea of "syndromic analysis", which involves discovering the central mechanism that underlies the difficulties encountered in the case. This cannot be obtained from numerical data, and neither can it be reduced to a description of the case. Rather, it requires identifying the working unit of the brain, a particular neuropsychological factor for the participation of cortical an / or subcortical elements of functional brain work. This mechanism or factor will determine the entire series of difficulties that children experience in their verbal, nonverbal activity, behavior and personality (Solovieva \& Quintanar, 2017a). Psychological syndrome analysis consists of contrasting types of errors and ways of obtaining assistance during the individual interactive evaluation with each patient. Errors must emerge systemically and constantly in order to clearly identify a specific neuropsychological syndrome.

In 1940, Luria began to compile three papers, all related to aphasia. The first presented an analysis of sensory aphasia, which was the subject of the author's doctoral thesis, defended in medical science in 1944. The second, about parietal aphasia or semantic aphasia, which was not concluded, contains syndromic analysis of language alterations caused by temporal, parietal and occipital lesions in the left hemisphere in relation to global visual perception, that is, simultaneous spatial synthesis and schematization of the patient's experiences as a follow-up from the body scheme to the amodal categories and conceptual schemes (Akhutina \& Agris, 2018). The third volume about motor aphasias was only initiated by Luria.

These materials demonstrate the particularities of Luria's neuropsychological approach as a systemic and interdisciplinary principle. Luria's literature quotes always refer to areas of neurology and linguistics, among others, with special emphasis on historical and social aspects in the analysis of psychological processes related to human activities and the evolution of symbolic systems, including language.

During the Second World War (1941-1945), Luria was the head of rehabilitation at the Military Hospital for evacuated military personnel in Kisegach, in the Southern Ural region (Cheliabinsk region). Based on clinical studies carried out before the war, his working group of more than thirty collaborators diagnosed and rehabilitated the psychological functions of patients with brain injuries. At another military hospital in a nearby town, rehabilitation work involved voluntary movements as a result of peripheral injuries, coordinated by A.N. Leontiev and A.V. Zaporozhets.

At the end of 1944, upon returning to Moscow and working at the Institute of Neurology and the Institute of Neurosurgery, Luria developed the studies that made him internationally acclaimed. These included "Traumatic Aphasia", published in 1947 and "Higher cortical functions", published in 1962. In the latter, Luria describes the basic neuropsychological syndromes that arise from injuries to different cortical sectors, along with the diagnostic methods that identify these alterations. A vertical approach was used that included various cortical 
and subcortical levels. Luria was primarily interested in "processes by which the brain produces and controls the level of its own activation" (Akhutina \& Agris, 2018). Luria's conception of three structural and three functional blocks of the brain (tone and wake regulation block, reception block, information processing and conservation, programming block, regulation and control of complex forms of activities) is based on this approach (Luria, 2003).

It is worth mentioning that Luria's concept of cerebral functional organization is widely known and referenced. However, the greatest difficulty in the methodological and clinical application of this concept lies in the limited understanding of the term beyond the more global conceptions, for example, outside the historical-cultural approach in psychology proposed by L. S. Vygotsky.

What is the relationship between these apparently different concepts?

The historical-cultural origin of the human psyche presumes a systemic and dialectical view of functioning at both the psychological and brain level. From this approach, brain blocks do not work separately to produce certain functions. The joint participation of all three functional blocks is absolutely necessary to ensure a task is carried out. An example of such a task is writing, reading a sentence or a child's drawing on a sheet of paper. The task can be constructive, with the use of concrete blocks or even objects, or related to mathematics, geometry or any other type of conceptual knowledge. Various tasks can be carried out at different levels of action: concrete material, concrete perceptive, materialized symbolic, schematic perceptual, oral verbal, written verbal, etc. (Galperin, 2000; Solovieva, 2014; Talizina, 2009). All of these tasks or actions are formed and acquired during the life of the subjects in their constant interaction (optimal or deficient) with other people in the world of cultural objects or units (Eco, 2005). This line of ideas unites us with the historical-cultural origin of the human psyche of the Vygotsky paradigm.

According to this systemic and dialectical view, because the three brain blocks participate in each of these tasks, it is impossible to propose individual tasks or "functions" for each block. When assessing subjects' performance of each task, neuropsychologists must identify the signs and evidence of the weakness in one of the three functional blocks, but cannot design and apply specific tasks for each one.

Naturally everything becomes even more complex if we consider that the participation of different cortical and subcortical mechanisms, within each of the three functional ones, is selective and varies with age, degree of automation or domain, depending on the content of each particular cultural action.

This position is alien to a traditional understanding of analysis and evaluation of cognitive functions separate from the search for a cerebral correlate for each function. This lack of understanding means that although Luria's work is cited, the methodology proposed is not understood or fully utilized.

\section{Conclusions and reflections}

This article considered the main ideas of L.S. Vygotsky and A.R. Luria and certain moments of the historical emergence of their ideas. What objective and specific traits were identified as unconventional?

First, the principle of the systemic structure of higher psychological functions assumes its complex systemic and hierarchical consideration. This structure varies and changes at different ontogenetic times, producing different qualitative levels. The systems are also altered by the cultural effects of the activity, labor, profession and forms of communication that individual subjects participate in during their lifetime. The hierarchical structure means that, at different psychological ages, different activities play a leading role. The complex psychological systems, which two of the authors of this article (Solovieva and Quintanar) prefer to call activities, are products of the life and interaction of human beings in culture, precisely through the performance of activities. The activity becomes an intermediate level or link that allows us to combine culture with the psychological processes of each subject that can only be formed in the activity and not outside it. Although psychological processes cannot exist without social and cultural life, the effects of this cultural environment do not arise spontaneously or immediately, but are mediated by the activity of each subject.

Psychological development as an acquisition of human cultural experience cannot exist without the participation of each subject as subjects of their own activity and the exchange with cultural objects that are both objects and subjects (Leontiev, 2009).

At the same time, the psychophysiological mechanisms of this activity (Gippenreitor, 1996; Leontiev, 2012) also acquire new, stable and flexible functional levels in this same activity and not outside it. These mechanisms are consolidated and united in complex functional systems (Anokhin, 1987) that underlie cultural actions, at the psychophysiological or neurophysiological level. Each 
action represents a complex psycho- and neurophysiological system. These complex functional systems cannot appear spontaneously, without participation in the motor and objective activities of real life.

This forms part of a conceptual logic that the brain is a material substrate of such activities, considering that the pathological, dysfunctional or injured status of a brain area in children and adults leads to different effects. Vygotsky's laws considered the participation of the lower and upper levels in cases of pathology of the central and peripheral nervous system in childhood and adulthood (Vygotsky, 2016).

These positions not only confirm the essence of the historical-cultural paradigm of development, but further consolidate them. Vygotsky's position on the principle of extra-cortical organization of psychological processes acquires greater importance and methodological value.

This principle means that the "brain lowers its own limits" or is formed in a space that lowers these limits, a space of intersubjective activity where several participants interact to achieve a shared objective. Not surprisingly, Vygotsky wrote that to understand "human thought, it is necessary to go beyond the limits of the human brain."

Consequently, it is understood that, according to the social origin principle of the human psyche, the source of development must not be sought within the brain or psyche, but in the relationships between people: in instruments, signs, and human language (Karmiloff-Smith, 2002; Luria, 1979).

The structure of higher psychological functions always assumes mediation through signs, language proficiency, and different inter and intracultural symbolic systems. All sign systems are undoubtedly products of past, present and future human history, because history never ends. This underlines both the social and historical origin of human processes. Everything discussed here confirms the need to study psychological and neuropsychological processes as flexible processes, constantly changing and developing.

It is important to note that the term "activity" better expresses and establishes the idea of social relations, referring not only to relationships, but the activity motivated and aimed at the objectives.

In addition to the above, psychological processes are considered systems in constant development, training that leads to high levels of self-regulation. This self-regulation is not manifested from the beginning, but is considered an ideal and dialectical possibility, as a potential for cultural development that is not decisive, but only probable under certain conditions.
The progressive formation of psychological processes according to the gradual internalization of external social interactions is a complex dialectical and dynamic process that is probable rather than mandatory. At a high level of functioning, psychological systems can be self-regulating and self-organizing (Zinchenko \& Pervichko, 2012). Luria, in turn, defined the higher psychological functions as "processes of complex self-regulation" "conscious and voluntary processes through their functioning" (Luria, 1969).

At the same time, Vygotsky and Luria postulate a dynamic and systemic organization of higher psychological processes with constant changes within ontogenesis. This principle is epitomized in the concept of guiding activities that lead to the creation of new psychological formations at various childhood ages. At each age, the possibilities of cerebral regulation and performing the same function with varied and diverse structures at different brain levels change (Akhutina \& Pilayeva, 2008). This position cannot be understood based on the cognitive paradigm that continues to seek the unique, eternal and innate correlates of cognitive functions of the cerebral substrate. Luria's idea is very similar to the notion of brain plasticity and flexible confirmation of cortical and subcortical systems (Bernstein, 2003).

This approach requires correlating different levels of psychological, neuropsychological, cultural and cerebral analysis, which changes the relationships between causes and effects from different levels and participation of the variable links. The tasks involved in the activities are always analyzed based on the real conditions in which problems and tasks are established, making it possible to identify the brain mechanisms that participate in the corresponding functional systems (Solovieva \& Quintanar, 2017b).

Thus, one can refer to a line of research and methodology of neuropsychology studies from the historical-cultural viewpoint, initiated by Vygotsky and Luria, but which has a considerable number of followers around the world.

\section{References}

Akhutina, T. (2002). Análisis neuropsicológico de la afasia dinámica. Moscú: Terevinf.

Akhutina, T., \& Agris, A. (2018). Etapas tempranas del estudio de la afasia semántica en los trabajos de A. R. Luria. Problemas de Psicolinguística, 1(35), 14-27.

Akhutina, T., \& Pilayeva, N. (2008). Superaciones de problemas de aprendizaje: aproximación neuropsicológica. San-Petersburgo: Piter.

Anokhin, P. (1987). Psicología y filosofía de la ciencia: metodología del sistema funcional. México: Trillas. 
Bernstein, N. (2003). Búsquedas actuales en la fisiología del proceso nervioso. Moscú: Sentido.

Eco, U. (2005). Tratado de semiótica general. México: De Bolsillo.

Galperin, P. (2000). Cuatro conferencias sobre psicología. Moscú: Escuela Superior.

Gazzaniga, M. (2012). ¿Quién manda aquí? El libre albedrío y la ciencia del cerebro. Madrid: Paídos.

Gippenreiter, Y.(1996). Introducción a la psicología general. Moscú: CheRo.

Karmiloff-Smith, A. (2002). Development itself is the key to understanding developmental disorders. In M. H. Jonson, Y. Munakata, \& R. O. Gilmore (Eds.), Brain development and cognition: A reader (pp. 375-391). Oxford, UK: Blackwell.

Leontiev, A. (1975). Actividad, consciencia, personalidad. Moscú: UEM

Leontiev, A. (1983). Obras psicológicas escogidas. Moscú: UEM

Leontiev, A. (2009). Bases psicológicas del desarrollo y la enseñanza del niño. Moscú, Sentido.

Leontiev, A. (2012). Evolución, movimiento, actividad. Moscú: Sentido.

Lotman, M. (2001). Semio-esfera. San Petersburgo: Arte-San Petersburgo.

Luria, A. (1969) Funciones corticales superiores del hombre y sus alteraciones ante lesiones locales cerebrales. Moscú: UEM.

Luria, A. (1979). Lenguaje y conciencia. Moscú: UEM.

Luria, A. (2003). Bases de neuropsicología. Moscú: Academia.

Machinskaya, R. (2012). ¿Para qué el psicólogo necesita el "cerebro social"? Psicología Histórico-Cultural, 8(4), 103-109.

Mahn, H. (2010). Vygotsky's methodological approach: A blueprint for the future of psychology. In A. Toomela \& J. Valsiner (Eds.), Methodological thinking in psychology: 60 years gone astray? (pp. 297-323). Charlotte, NC: Information AgePublishing.

Solovieva, Y. (2014). La actividad intelectual en el paradigma históricocultural. México: CEIDE.

Solovieva, Y., \& Quintanar, L. (2017a). Psychological concepts of activity theory in child neuropsychology. Journal of Education and Culture Studies, 1(1), 25-41. doi: 10.22158/jecs.v1n1p25
Solovieva, Y., \& Quintanar, L. (2017b). Syndromic analysis in child neuropsychology: A case study. Psychology in Russia: State of Art, 10(4), 172-184. doi: 10.11621/pir.2017.0415

Kiyaschenko, L., \& Stiopin, V (2009). Ciencia post no clasica: filosofía, ciencia, cultura: monografía colectiva. San-Petersburgo.

Talizina, N. (2009). Aplicación de la teoría de la actividad a la enseñanza. México: Universidad Autónoma de Puebla.

Toomela, A. (2014). There can be no cultural-historical psychology without neuropsychology. And vice versa. In A. Yasnitsky, R. Van Der Veer, \& M. Ferrari (Eds.), The Cambridge handbook of cultural-historical psychology (pp. 315-349). New York: Cambridge University Press.

Veresov, N. (2010). Forgotten methodology: Vygotsky's case. In A. Toomela \& J.Valsiner (Eds.), Methodological thinking in psychology:60 years gone astray?(pp. 267-295). Charlotte, NC: Information Age Publishing

Vygotsky, L.S. (1982). Obras escogidas. Tomo 1. Moscú: Pedagogía.

Vygotsky, L. S. (1983). Obras escogidas. Tomo V. Moscú: Pedagogía.

Vygotsky, L. S. (1984). Obras escogidas. Tomo VI. Moscú: Pedagogía.

Vygotsky, L. S. (1995). Problemas del desarrollo y desintegarción de las funciones psíquicas. In T.M. Lifanova (Ed.), Problemas de defectología (pp. 404-418). Moscú: Ilustración.

Vygotsky, L. S. (2016). El desarrollo del Sistema nervioso. In L. Quintanar \&Y.Solovieva(Eds.), Las funciones psicológicas en el desarrollo del niño(pp. 21-36). México: Trillas.

Xomskaya, E. D. (2005). Neuropsicología. San-Petersburgo: Piter.

York, G., \& Steinberg, D. (2006). An introduction to the life and work of John Hughlings Jackson with a catalogue raisonné of his writings. Medical History, 50(Suppl. 26), 1-34. doi: 10.1017/S0025727300071994

Zavershneva, E. (2008). Notas, anotaciones y diarios científicos de L.S. Vygotsky: resultados de los estudios del archivo familiar. Problemas de Psicología, 2, 120-136.

Zhdan, A. (2004). Historía de psicología: desde la antguedad hasta nuestros días. Moscú: Proyecto Académico.

Zinchenko, Y. P., \& Pervichko, E. I. (2012). Metodología post no clásica en la psicológica clínica: escuela científica de L. S. Vygotsky y A. R. Luria. Revista Psicológica Nacional, 2(8), 32-45.

Yulia Solovieva, doutora em neuropsicologia, é professora na Benemérita Universidad Autónoma de Puebla (BUAP). E-mail: yulia.solovieva@correo.buap.mx

Luis Quintanar Rojas, doutor em neuropsicologia pela Moscow State University, é professor na Benemérita Universidad Autónoma de Puebla (BUAP). E-mail: luis.quintanar@correo.buap.mx

Tatiana Akhutina, doutora em ciência pela Moscow State University, é chefe do Laboratório de Neuropsicologia da Moscow State University. E-mail: akhutina@mail.ru

Izabel Hazin, doutora em psicologia cognitiva pela Universidade Federal de Permambuco, é docente na Universidade Federal do Rio Grande do Norte. E-mail: izabel.hazin@gmail.com

Received in 10.april.19 Revised in 24.sep.19 Accepted in 10.dec.19 